\title{
BIOINDICATION AS CHALLENGE IN MODERN ENVIRONMENTAL PROTECTION
}

\author{
BIOINDYKACJA WYZWANIEM NOWOCZESNEJ OCHRONY ŚRODOWISKA
}

\begin{abstract}
Research into and diagnosis of environmental change prior to the introduction of bioindicator methods were linked primarily to apparatus. Drawing attention to the reactions of organisms sensitive to that change and using them in environmental quality control have opened new opportunities for development of a new scientific discipline, known in the literature as bioindication. Bioindication combines several scientific disciplines, including biology, broadly conceived geography, and chemistry. It thus combines in a comprehensible manner apparatus-derived measurements (chemical analysis results) and areas of bioindicator exposure (situation and distance from the emitter), translating these parameters into bioindicators' anatomical and morphological reactions. The development of bioindicator methods progresses rapidly, and - as is usually the case under such circumstances - it is difficult to ensure that they are transparent and that no chaos ensues. In view of the above, it seems necessary to embark on a discussion of these issues and consider compiling lists of most applicable indicator organisms for examination of particular environmental toxins in particular environments.
\end{abstract}

Keywords: environmental pollution, bioindicators, bioindication research, bioindication methods

\section{Introduction}

Since the beginning of the twenty-first century, bioindication has been in its heyday. This is primarily a consequence of the need to assess the impact of very dynamic civilisational progress on living organisms. Information on the volume and type of air, water or soil contamination is no longer sufficient. At present, there exists demand for information on living organisms' reactions to the changes which occur in the environment under the influence of xenobiotics.

All this poses a challenge to environmental protection, which - according to the regulation of the Minister of Science and Higher Education - has been a scientific discipline since October 1, 2011. This was a momentous decision both for scientists dealing with environmental protection and research units in whose names environmental protection is inscribed.

\footnotetext{
${ }^{1}$ Department of Environment Protection and Modelling, Jan Kochanowski University, ul. Świętokrzyska 15, 25-406 Kielce, Poland, phone +48 4134964 27, fax +48 4134964 18, email: malgorzata.jozwiak@vp.pl, marjo@ujk.edu.pl

*Corresponding author: malgorzata.jozwiak@vp.pl
} 
Each scientific discipline ought to have its own research field as well as well-defined research methods and methodology. Environmental protection is presently facing this kind of challenge. So far, the discipline has been using research methods of several scientific disciplines, including biology, chemistry, geography or physics. We believe that bioindication and methods used therein ought to constitute the basis for contemporary environmental protection.

\section{The history of bioindication research}

The history of bioindication dates back to the eighteenth century. Carl Linnaeus (1730) coined the notion of the "floral clock" when watching blossoms at the Uppsala Botanical Garden open at different times of day. While Linnaeus is credited with the idea of creating a biological clock, it is worth quoting Pliny the Elder (23-79 CE), who wrote: "Nature seems to be calling to man: Why raise your eyes to the skies? I have given you plants which tell time".

The late eighteenth century brings the discoveries of Alphonse de Condolle, who highlights the links between plants and climatic factors. The earliest mentions of organisms being used to assess the quality of the natural environment are found in 1866. Changes to lichen biota were then described and linked to the changing quality of atmospheric air. The turn of the nineteenth century is notable for its rapid development of paleobotany and paleozoology. These sciences use plant and animal remains as index fossils for rock dating. This kind of research was conducted by William Smith. The works by Grindon (1859) bring the first information on the use of lichens for atmospheric air pollution control (the 1850s and the 1860s) [1]. In 1875, Cohn, and then Kolkwitz and Liebmann (1962) point out that occurrence of particular species of plankton, periphyton and benthos in the water or the typical macrophytes of water biotopes may serve as a basis for assessing the extent of water pollution with organic compounds. From 1894 onwards, Merrian's research uses plants as indicators of temperature zones. W. Nylander, a Belgian (1866), and S. Arnold, a German (1892), conduct a wide range of research into lichen sensitivity to air pollution $[1,2]$. The following years bring new information on the use of organisms for assessment of the environmental condition. In 1902, Kolkwitz and Marsson publish their first saprobic system which monitors the purity of a water environment with the use of bioindicators. Shautz (1911) and Clements (1916) draw attention to the fact that the flora list of a particular area is affected by hydrologic conditions and soil fertility. As a bioindication research, pollen analysis method is first used by Leonard von Post in 1916 as he announces the first results of palinological examination of peat bogs. In the context of pollen analysis, paleoecological research is retrospective as it enables recreation of past climatic and edaphic parameters by using bioindicator properties of certain plant species.

The first lichenoindicator maps which demonstrate correlations between lichen zones and species lists are developed in the 1930s. They are drawn by Haugsjå for Oslo in 1930 [3]. In 1954, Cannon demonstrates possibilities for the use of vegetation as indicator of metal deposit location. In 1968, at Vageningen, the First European Congress for the Impact of Air Pollution on Plants and Animals is held. At the Congress, lichen and bryophyte transplantation methods are presented for the first time [4].

Later research, together with subsequent publications, enlarges on these issues [5-7]. The gradual reduction of tree epiphytes in south-eastern England over two hundred years 
(1784-1997), resulting from the income of air masses contaminated with sulphur compounds from over London, is noted by Forster, Cromble, Paulson and Thomson, as well as Rose and Pentecost [1]. In this way, the connection between increased air pollution and the species list of epiphytic lichenobiota is established.

Last but not least, in 1986, the negative influence of air, water and soil pollution on living organisms receives worldwide recognition. These issues come to constitute research objectives for numerous research centres and laboratories, following the memorable statement by Mobius: "Groups of living organisms and their living conditions correspond to particular sets of environmental conditions".

Research programmes appear which offer a complex perspective on the problems of environmental protection. They unequivocally highlight the need for international co-operation. An example is a monitoring programme aimed at discovering the contamination of the European Continent with heavy metals. In recognition of high biomonitoring value of mosses, they are used as environmental pollution indicators. The programme is implemented by a group of Scandinavian ecologists, NEG for HMD (Nordic Expert Group for Heavy Metal Depositions), in the early 1980s. Their first studies cover only Sweden, Norway, Finland and Denmark [8-13]. By 1990, this international programme is joined by as many as twenty-one European states, including Poland [14].

\section{Bioindication research in Poland}

Poland's first researcher in biomonitoring with the use of mosses is Professor K. Grodzińska, together with the team of the Polish Academy of Sciences' Institute of Botany in Krakow [15-19]. Local-scale studies with the use of mosses as bioindicators are conducted by Makomaska [20]. The research field is the Białowieza and Niepolomice Forests. Mosses are also used as indicators in the analysis of air contamination in Krakow [21]. Indicator studies with the use of the Pleurozium schreberi moss, obtained from natural biotopes, are conducted by Godzik, Kiszka [22], Godzik, Szarek-Łukaszewska [23]. In the 1980s, bioindication of atmospheric air becomes the subject of studies by Fabiszewski [24]. They rely on phytoindication for monitoring and assessment of copperworks impact on plant organisms. The influence of cement and lime industry contaminations on lichens is investigated by Cieslinski and Jaworska [25]. In 1988, in the Chelm voivodeship, environmental contamination zones resulting from pollution basing on licheno- and bioindication are determined by Bystrek [26]. Also in 1988, Seaward [27] and his team assess air contamination with heavy metals and radionuclides with the use of lichens in south-western Poland. In 1990, Kiszka and Piorecki [28], as well as Czarnota [29] in 1995 and 1999 use bioindicator properties of lichens to examine the areas of national parks. Likewise, within the Integrated Monitoring of the Natural Environment, Sawicka-Kapusta and her team carry out assessment of the quality of atmospheric air in selected national parks [30] by testing heavy metals in the thalli of Hypogymnia physodes. In Poland, bioindicator methods are used to test many areas threatened with environmental disaster. The major ones include Upper Silesia, the city of Krakow, as well as the Legnica and Glogow Coal Basin. From 2004 onwards, in the Kielce agglomeration, the impact of municipal, transport and industrial (mostly from the cement and lime industry) pollution is examined in the thallus of the Hypogymnia physodes lichen, used as atmospheric air bioindicator [31-33]. 
In Poland, bioindicator studies of the water environment are also conducted. In 1979, Turoboyski adopts the saprobic method for assessment of water purity under Polish conditions. Afterwards, this is followed by proliferation of studies into watercourses and lentic waters. Serafiński et al [34] suggest bioindicator use of malacofauna by applying the Planorbarius corneus with its capacity for lead accumulation in the shell and tissues. In the 1980s, Pieczyńska [35] points to the significance of macrophytes in lake ecotone zones for the shaping of lake trophie. Strzelec and Serafiński [36], as well as Strzelec [37] investigate the malacofauna of post-mining exploitation reservoirs by assessing the impact of water temperature increase on studied snail species. Assessment of river and lake quality through assessment of their ecological condition constitutes a new approach to monitoring, implemented in the entire European Union. At present, biological assessment of water quality is carried out on the basis of numerous macroinvertebrate species in both benthic and pelagic zones [38]. The assessment relies on the new criteria which pertain to all types of surface waters and comply with the requirements of the 2000 EU laws as well as 2002 Polish laws, based on the 2000/60/EC Directive, known as the Framework Water Directive (FWD). In 2006, to meet the needs of monitoring Poland's flowing waters, the employee team of the Chair for Ecology and Environmental Protection at the University of Natural Sciences in Poznań develop the "Macrophyte Method for River Assessment", based on macrophyte reactions to water biotope degradation. This method is devised on the basis of macrophyte methods used in the British (Mean Trophic Rank - MTR) and French (Indice Biologique Macrophytique en Riviére - IBMR) systems, adapted to climatic, geological and biological conditions of Polish flowing waters [38].

\section{Bioindication methods}

The development of bioindicative methods dates back to the beginning of the $\mathrm{XX}$ century. In the $60 \mathrm{~s}$ there was a growing interest of natural sciences in problems connected with reactions of living organisms to pollution (Brodo 1961). It was observed that the reactions to toxins are the results of fast development of industry, automotive industry, chemication of life and they concern pollution of water and land biotypes. Bioindicative qualities of plants were noticed by Ellenberg [40] and he proved the possibility of their use in estimation of edafic condition, climatic conditionsand the intensity of antropopressure. Such estimation was and has been possible because of diversified sensitivity of living organisms to environmental conditions.

The reactions of organisms to stress due to the different requirements of biotope and species diversity is not carried out by the life processes (photosynthesis, respiration, cellular oxidation, photorespiration, reproduction, intra-and extracellular transport, histoliza in metamorphoses, phenological stages). Ellenberg [41], Barker [42], Bick [43], Burton [44] noticed this problem. Analyzing the role and sensitivity of reactions to a stressor, bioindicators were classified (Fig. 1).

The first period of the development of techniques and bioindicative methods came down only to description of the impact of toxic substances on the group of organisms and disorders in trophic chains resulting from the presence of toxins in the biotope. At the same time the first method of analysis and mathematical methods of their calculation were created (EC50 - probit method, the standards ASTM - American Society for Testing and Materials, using fish to describe the symptoms of poisoning). There was also a discussion started on 
the purpose of the bioindicative study, whose effect was an apparent separation of bioindication in two directions. They were subjected to designate biotype studies under the influence of various chemical compounds and study of human environment using indicator organisms (Fig. 2).

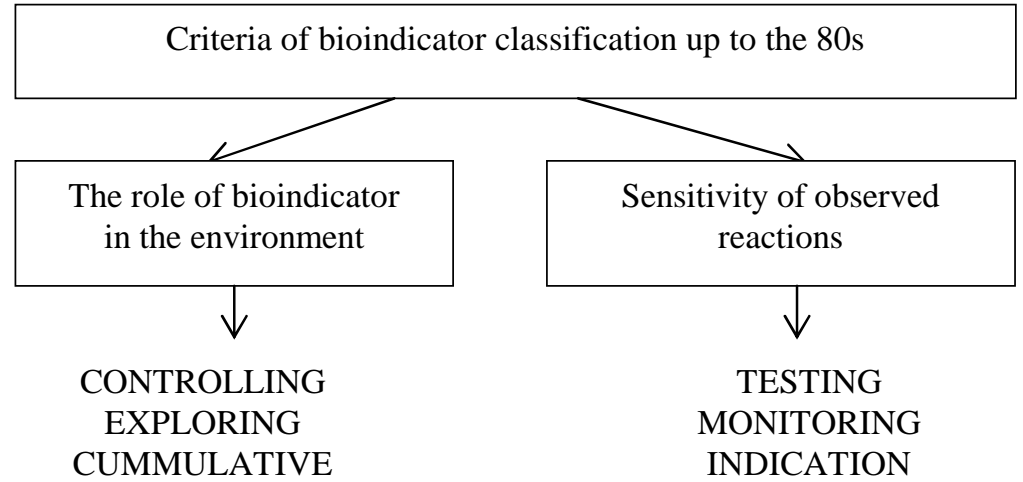

Fig. 1. Criteria of bioindicator classification [33]

\section{BIOINDICATION}

ENVIRONMENTAL DIRECTION

It studies the impact of these pure chemicals and waste on the environment on the basis of selected ecosystems, biocenosis or aquatic or terrestrial species

Fig. 2. Bioindication directions [33]

This discussion was only theoretical in nature, allowing for research, resulting in measurable results and it did not overshadow the important environmental issues Bioindication permanently inscribed itself into environmental research and is one of the modern and essential elements of environmental control.

During the biomonitoring studies toxicological evaluation of various parameters biotope is made. There are the issues of classification of these parameters and their effects on living organisms and the probability of the negative impact of the tested parameter associated with it. The level of toxicity of the dose is determined that it is found in the environment, its toxic effects, the ability to predict the long-term effects in organisms which 
occur after the time of exposure to the toxin, the ability to assess whether the tested parameter is mutagenic, cancerogenic, teratogenic or embryotoxic in the test organism.

Currently, research and environmental control using bioindicative methods are used in many countries of Europe and the world [45-50].

There are universal methods and indicators described, which are then used in accordance with accepted standards of assessment criteria allowing changes in the environment and comparability of the results of the analyzes. They are also used to systematize the bioindicative method and characteristics of the dynamic of the changes taking place in nature. In the first study biomonitoring lichens are used as biomarkers. These studies have provided theoretical and practical foundation of biomonitoring. The development of lichenoindication caused extensive use of lichens in bioindication in different regions of the world: the Netherlands [51], Finland (Garty et al [52]), Argentina (Gonzalez et al [53], Carreras, Pignata [54] Calvelo, Liberatore [48]), USA (Malkholm Bennett [55]), Germany (Jensen et al [56]), Italy (Conti, Cecchetti [57], Conti et al [49]), Poland (Białonska [58] Sawicka-Kapusta et al [59], Jozwiak [60], Godzik, Szarek-Lukaszewska [23]), Chile (Cortes [61]), Portugal (Godinho et al [62]), Slovenia (Policnik et al [63]), Israel (Garty et al [64]), Denmark (Vestergaard et al [65]), Lithuania (Motiejunaite [66]).

Together with the development of analytic methods, transplantation method of different species is more frequently used [30, 44, 57, 60, 67, 68].

Experiments on the transplantation of lichen, that is moving them from areas of low contamination (forests, national parks, rural areas retain the original character of the landscape) areas where lichens are not found in natural clusters (lichen deserts) or their presence is significantly limited due to the influence of anthropogenic, began in the late nineteenth century. The study consisted of the observation of morphological changes, and macroscopic defects in thalli [69]. Moving lichen thalli living in contaminated areas, their exposure in selected points, depending on the sources of emissions and subsequent chemical analysis allows to determine the risks from the standpoint of human health protection.

Another taxon successfully used in transplantation methods are mosses. They are defined as outstanding battery of heavy metals. Heavy metal ions absorb mainly from precipitation and dry deposition. They take them through a process of ion exchange. Some species have a storied composition, and the annual increase forming distinct segments indicate the year of pollution accumulation $[2,8,15]$.

Mosses are used to determine the environmental changes both in very large and small areas, global, national, regional, and local. They are used to assess the level of contaminants in a given unit of time, over a few tens or even hundreds of years, as shown in the work of Grodzinska et al [17, 18] and Ruchling et al [14].

Red Hybrid of California is used [Eisenia faetida (Sav.)] is used with a large environmental effect which allow the assessment of the type of contaminants present in soil [70]. This worm immobilizes the most toxic and car carcinogenic pollutants absorbed into the soil. These are oil derivatives, such as benzene, toluene, ethyl benzene, polycyclic aromatic hydrocarbons and heavy metals xylenes. Eisenia faetida (Sav.) accumulates organic compounds, such as chlorophenols, TNT (trinitrotoluene), and also processes the organic municipal waste, leaving in the tissues toxic metabolites [70, 71]. Its usefulness in the assessment of environmental pollution of the soil consists of a high resistance to toxins, 
the possibility of long term observations and studies of the level of concentration of pollutants due to its longevity and high adaptability.

Water protection and proper management of water resources is possible, if there are records of areas established for the protection of surface water and groundwater. The key issue is the assessment of biological values of tanks. They influence the directions of the potential destination of the basin [72]. Evaluation of the purity of the aquatic ecosystem based on bioindicative organisms provides an indication of the capacity of the reservoir to toxins and consequently elimination of chemical contamination of water and sediments, which helps to improve the oxygen balance, maintaining biodiversity, of flora and fauna [73].

Evaluation of the tanks is based on the concentration of heavy metals in water, sediments and detrytophagic shellfish organisms. The use of molluscs to examine the concentration of heavy metals is well documented in the literature [74-80], because the use of these organisms in the bioindication methods gives a good basis for the control of water surface.

The most frequently used bioindicative species are snails Lymnaea stagnalis (Linnaeus 1758), Planorbarius corneus (Linnaeus 1758), Physella acuta (Drapar Draparnaud 1805). These species have a high capacity to accumulate the heavy metals, which results from the type of food drawn (bottom sediment, detritus) and a water filter [81]. They meet the basic criteria for indicator species of aquatic ecosystems [82], which include: bioaccumulation of heavy metals, low sensitivity to pollution, including those related to transportation, well-established biology and the presence of a sufficiently large [83].

Bioindication methods which aim at controlling condition of environment are underestimated in Poland and are not fully used in research. The comparison of the scope and variety of research in Europe and all over the world with those conducted in Poland are to Poland's disadvantage. Most of native analysis mainly concern indicating the level of toxin concentration in bioindication organisms. There are few researches which evaluate and translate the level of accumulated toxins to characteristic reactions in tissues, cells and morphology used in biomonitoring of indicative organisms. That is why, detailed analysis of types of reactions and changes in bioindication organisms should be significant scope of research and niche to be filled in. Differentiating types of reactions such as colour changes, shape, size of organism and initial places of reactions to toxins, increasing or decreasing reproductiveness, size of population depending on the type of reacting toxin give advantage to bioindication research and equipment research.

It was noticed that there is a morphological changeability of observed species which appears as a result of interacting anthropogenic sensor (Hypogymnia physodes) diversified sensitivity of organisms and areas of initial reactions of organisms to toxins (Hypogymnia physodes) and changes in the size of population (Eisenia fetida, Physella acuta) [33].

In the research on toxin concentration level in bioindication organisms analytic methods were used which had not been used before in environmental research such as research with microanalyser EDS used in scanning microscope, thermal analysis using derivatograph system, Fourier Transform Infrared Spectroscopy (FTIR) analysis carried out with the use of 585 Brucker apparatus coupled with thermo gravimetric analyzer.

It was assumed that introducing new methods of research of biological material may lead to thorough multifaceted analysis and broadening the possibility of result interpretation. Undoubted innovation in conducted research are attempts to determine 
places of toxin deposition in organisms of bioindicators accurately (cracks of pesudocyphela, labial soralia, surface of algal and fungal cells present in dualistic structure of lichens, leaf base and ribs of mosses) The new element of bioindication research proposed in this study is the experiment with the use of Eisenia fetida in which survival and reproductiveness and cumulative ability of earthworm towards toxins which have not been tested so far and which create serious environmental problem, such as Diene rubber cis 1,4 polibutadiene, acrylonitrile-butadiene rubber.

One of the most significant elements of the research is the introduction of new species of snail Physella acuta to bioindication list, which, because of its dynamically broadening range of existence and the ability of living on dead organic substance meet the requirements for bioindicators. Broadening the range of warm waters of Mediterranean zone in the Northern Europe and settling inland basins, mainly their shallow inshore zones, preying places of this species is the result of global warming which is the basic feature of indicative ability of described species.

Microscopic analysis of lichens showed the effect of primeval changes described as the decline of final parts of lichen and as a consequence as the lack of labial soralia and the lack of reproduction possibility of lichens as a secondary effect. It was showed that there are tight connections between drastic changes and the dates of exposition. It was shown that the most extensive and the most common necrosis and thallus colour changes in final parts with damaged sorallia appear in summer months

The most common changes in lichen morphology concern thallus deformation (85 to $90 \%$ ) as well as lack of thallus growth. They are the result of marginal breaking and crumbling (76-91\%). Morphological reactions were also connected with their color (70-85\%). Electron samples analyzed in transmission microscope obtained from areas of thallus color changes unambiguously showed the order of appearing and stages of decomposition of chloroplast thylakoid membranes (places of thallus whitening which lead to dying of algal cell, and as a consequence creating fungal-algal haustorium (places of thallus browning without alga) and as a result creating necrotic blackened places with dead mycelium.

Conducted observation leads to the conclusion that the changes appear in a certain order and they have a growing characteristic. Transmission analysis of photobiont and mycobiont cells concerns mainly the observation of chloroplast structure in algal cells and fungal cell membranes. There were some deformation of star-shaped chloroplast found in Trebouxia sp. cells, stratification of thylakoid membranes, pyrenoid disintegration and pirenoglobuli dispersion, exposing larde places of deutoplazma, atrophy of external membrane of plastid.

In places of tight contact of hyphae with algal cell wall outer algal-fungal haustorium were found. In samples exposed in extreme conditions of anthropressure (crossroads with heavy traffic) internal haustorium in which hyphae penetrate deep inside algal cells changing types of algal-fungal interaction from mutualist to parasitic were found.

Thallus observation conducted in scanning electron microscope showed that bioindicator is capable of defensive reactions. They are manifested by production of gel or chelatous nets as a result of reaction of metal positive ions with secondary lichen metabolites of Hypogymnia physodes such as physodiac phosidiac and fumaroprotocetrariac acid. Arising, visible under microscope, net or mucilage covers the surface and intercellular spaces of lichen. Because numerous chemical analysis showed the presence of heavy metals 
(positive ions $\mathrm{Cu}^{2+}, \mathrm{Al}^{3+}, \mathrm{Zn}^{2+}, \mathrm{Fe}^{3+}, \mathrm{Mn}^{2+}$ ) the presence of binding chelates is proved by pollution of examined environments.

Electron microscopy makes determination of ways of immission into bioindicator organism possible. This research unambiguously showed that the main spaces of pollution penetration inside lichen thallus are places of mycelium loosening which is characteristic of labial soralia marginally located and respiratory cracks of pseudocyphela located on the surface of thallus. The above research proved the protective function of cortical layer of thallus composed of thigh thick-walled mycelium. The basis of these conclusions was the analysis of level of heavy metal concentration on the surface of upper cortex and directly underneath carried out with the use of EDS microanalyzer.

One of the vital elements of bioindicative research is a fast diagnosis of the unfavorable influence on bioindicator organism. It is possible if the researcher is able to estimate the difference in morphological features of healthy organism and organism changed by environmental toxins. Using Pleurozium schreberi it was observed that the moss morphological features appear as a change in vegetative organs.

In the picture of analyzed microscopic changes in leaves of Pleurozium schreberi it was observed that there are extensive colour changes in the central part of leaf blade together with leaf rib and the leaf base. Colour changes showed diversified scope and were placed in range from 250 and $400 \mu \mathrm{m}$ of the width of leaf up to $600 \mu \mathrm{m}$ of its length.

Changes in leaf rims and tube-like rolled leaf blade edges were not observed, which is the result of characteristic of this moss species gutter-like construction of leaf blade. Naturally shaped, spoon-like concave leaf blade makes ion forms of heavy metals dissolved in rainfall lie at the bottom of leaf gutter, which favours their bioaccumulation processes.

Facilitating the absorbtion of toxins (ectohydrity) in this leaf parts was the result of their anatomic composition on account of the lack of upper protective skin (the lack of drainage layer). Choosing the mosses as bioindicators only certain species should be taken into consideration.

One of them is Pleurozium schreberi used in research because its features of morphological composition, thickness of leaves, spiral way of gametophyte leaf arrangement on stalk and the shape of leaf blade influence the intensity of bioaccumulation because of the facilitated possibility, and large area of toxin accumulation. Such features are nor demonstrated by species like Polytrichum commune Hedw.

The new method of transplantation proposed in research, in which there are conditions maximally resembling those present in natural locations (dense turfs placed on the ground), was experimentally proven useful because of the possibility of pollution accumulation and macroscopic and microscopic observation. Applying the proposed method of transplantation in chosen places of exposition allows the researcher to compare the results of examination of mosses taken from their natural location with chosen research areas. The advantage of this research is the elimination of natural barrier impact, such as tree crown and green layer in forest ecosystems, on pollution accumulation, which directly influence the intensity and speed of toxin imission inside tissues. The proposed method allows precise determination of exposition time.

In research of soil pollution with the use of Eisenia fetida $\mathrm{Ca}$ and $\mathrm{C}$ content in tissues, excrement and vermicompost produced by earthworm was observed. Calcium is significant in digestive processes of Eisenia fetida and carbon in tissue composition of this species. 
The level of accumulation shown in percentage by weight and atom in tissues increases in time in relation to carbon and after 9 months of preying on the surface polluted with fuel $30 \%$ increase of its amount was observed, which proves that this element was built in tissues.

There was also accumulation of heavy metals in earthworm tissues. The highest level of toxin accumulation was observed in case of $\mathrm{Pb} 24.75$ times more in relation to control sample and Cd - 1.44 times more, Zn 0.55 times more. Because of the high level of toxicity of these elements and survival ability of earthworm in these conditions we should point out the adaptation ability and indicator resistance to pollution introduced in biotype.

The estimation of the use of Eisenia fetida to control the environment polluted with rubber caoutchouc of cis-1.4-polybutadiene rubber (BR) on the basis of birth rate which showed growth tendency despite permanent toxin presence in environment which proves adaptive ability of Californian earthworm.

It was found that there is a full life cycle with all the stages (cocoon stage, colorless stages of young forms, colorless stages of reproductively mature forms). The increase in number of Californian earthworm in each stage of life cycle was gained, which may prove that introducing vulcanizate of butadiene rubber inside the soil with Californian earthworm, thanks to its trophic activity, leads to its complete decomposition, which is proved by derivatographic analysis of control samples, and it does not hinder reproductive processes of earthworm.

The control of cleanness of inland basins may be conducted thanks to estimation of chemical composition such biotype elements as water or bottom sediment. Organisms which live in inland basins are a very important element of water ecosystem. Hence, it seems justified to connect apparatus analysis of water with dynamic of the size of population of bioindicative organisms, especially if habitat requirements of the species are in close relation with settled biotype.

The research carried out in this matter used new and so far not used in biomonitoring species of snail Physella acuta, detritivore species praying on bottom sediments. It was shown that there is a relation of heavy metal accumulation which in order water-bottom sediment-mollusks, and it was demonstrated to what extend chosen snail meets the requirements given to bioindicators estimating indicative value of the species.

According to the Jozwiak [33] an extremely valuable research result was diversified order of the levelof element concentration (for $\mathrm{Zn}$ in order: water < sediment < mollusk; for PB water < molusc < sediment, for Cd there are divergences depending on the date of research and for the $2^{\text {nd }}$ quarter assumes the order: mollucs $<$ water $<$ sediment, $3^{\text {rd }}$ quarter water $<$ sediment $<$ molluces). The presented relation leads to statement that in case of $\mathrm{Zn}$ its main source in bioindicator organism in detritus which is bottom sediment, in case of $\mathrm{Pb}$ and $\mathrm{Cd}$ both water and taken in form of sustenance detritus.

Ecological condition of water basins was estimated on the basis of the amount of collected biological material in correlation with the date of sample collection, $\mathrm{pH}$ of water, the results of conductivity were analyzed and impact of this parameter on the number of collected snails from Lymnaea, Physella, Planorbarius family. The results obtained unambiguously proved the most dynamic increase of the size of population of Physella snails in relation to the others analyzed in the same biotype conditions. 
Ecological niche settled by Physella snails is the zone of shallow ecoton of the shore of basin with preferences of S-W direction, in relatively high temperature of feeding ground waters $\left(14^{\circ} \mathrm{C}\right.$ - early spring months up to $17^{\circ} \mathrm{C}$ in summer month).

Morphological features of examined basin which are the research area prove that they are not deep basins with large area of water level. Because of the relatively low depth there are no stratification processes in them, which leads to water heating equally in the whole perpendicular of water.

\section{Conclusions}

Research into and diagnosis of environmental change prior to the introduction of bioindicator methods were linked primarily to apparatus. Drawing attention to the reactions of organisms sensitive to that change and using them in environmental quality control have opened new opportunities for development of a new scientific discipline, known in the literature as bioindication. Bioindication combines several scientific disciplines, including biology, broadly conceived geography, and chemistry. It thus combines in a comprehensible manner apparatus-derived measurements (chemical analysis results) and areas of bioindicator exposure (situation and distance from the emitter), translating these parameters into bioindicators' anatomical and morphological reactions. The development of bioindicator methods progresses rapidly, and - as is usually the case under such circumstances - it is difficult to ensure that they are transparent and that no chaos ensues. In view of the above, it seems necessary to embark on a discussion of these issues and consider compiling lists of most applicable indicator organisms for examination of particular environmental toxins in particular environments. An equally significant element of bioindication research is methodology. The literature of the subject presents an enormous range of methods in use. This fact raises a number of questions and reviewers of scientific papers and communications are right to question juxtapositions of pollutant cumulation in lichen thalli exposed in sheltered locations and directly on tree trunks for instance, or of mosses in natural habitats (mostly obtained from forest groundcover) and those suspended in mesh bags from tree branches. Another example may be comparing the bioindicators of lothic and lentic water environments, which display markedly different pollutant concentrations in bioindicator organisms due to water dynamics.

Standardisation of research methodology will create opportunities for comparing results of studies conducted locally as well as those obtained in various countries or continents. Due to the highest merit of bioindication studies, which is organism reactions to toxins as early warning systems for humans, research with the use of bioindicators must progress. Yet a serious challenge in this field is to develop consistent and standardised research methods, and pinpoint the most valuable indicators in connection with the environment. The merit of bioindicator methods lies in the low costs involved, opportunities for long-term observation of processes which occur in ecosystems, and - consequently arriving at assessment of impact of natural or anthropopressure-related factors on populations and their condition within the studied biocenoses.

\section{References}

[1] Bates JW. The effects of impacts on bryophytes and lichens. Air Pollution and Plant Life. 2004;2:345-384. 
[2] Tyler G. Bryophytes and heavy metals: a literature review. Bot Jourin Linnea Soc. 1990;104:231-253. DOI: $10.1111 /$ j.1095-8339.1990.tb02220.x.

[3] Haugsjå PK. Über den Einfluß der Stadt Oslo auf die Flechten - vegetation der Bäume. Nyt Mag Naturvidensk. 1930;68:1-116.

[4] Mickiewicz J, Dygna S. Outline of biology. Warszawa: NSP; 1973.

[5] Gilbert OL. Further studies on the effect of sulphur dioxide on lichens and bryophytes. New Phytol. 1970;78:605-627.

[6] Gillbert OL. A biological scale for the estimation of sulfur dioxide pollution. New Phytol. 1970;79:629-634.

[7] Hawksworth DL, Rose F. Lichens as pollution monitors. London: Arnold; 1976.

[8] Rühling A, Tyler G. Heavy metal deposition in Scandinavia. Water Air Soil Pollut. 1973;2:445-455. DOI: 10.1007/BF00585089.

[9] Rühling A, Tyler G. Changes in the atmospheric deposition of minor and rare elements between 1975 and 2000 in south Sweden, as measured by moss analysis. Environ Pollut. 2004;131:417-423.

[10] Pakarinen P, Tolonen K. Regional survey of heavy metals in peat mosses. Ambio. 1976;5:38-40.

[11] Pilegaard K. Heavy metals in bulk precipitation and transplanted Hypogymnia physodes and Dicranoweisia cirrata in the vicinity of a Danish steelworks. Water Air Soil Pollut. 1979;11:77-91. DOI: 10.1007/BF00163521.

[12] Gydesen H, Pilegaard K, Rasmussen L, Ruhling A. Moss analyses used as a means of surveying the atmospheric heavy metal deposition in Sweden, Denmark and Greenland in 1980. Bulletin SNV PM. 1983;1670:1-44.

[13] Rühling A, Rasmussen L, Pilegaard K, Makinen A, Steinnes E. Survez of atmospheric heavy metal deposition in the Nordic countries in 1985 monitored by moss analyses. Nord. 1987;21:1-44.

[14] Rühling A, editor. Atmospheric heavy metal deposition in Europe-estimations based on moss analysis. Nord. 1994;9:9-53.

[15] Grodzińska K. Mosses as a bioindicators of heavy metal pollution In Polish National Parks. Water Air Soil Pollut. 1978;9:83-97.

[16] Grodzińska K. Contamination with heavy metals Polish national parks. Natural Protect. 1980;43:9-27.

[17] Grodzińska K, Szarek G, Godzik B. Heavy metal deposition in Polish National Parks. Changes during ten years. Water Air Soil Pollut. 1990;49:409-419.

[18] Grodzińska K, Szarek-Łukaszewska G, Godzik B. Survey of heavy metal deposition in Poland using mosses as indicators. Sci Total Environ. 1999;229:41-51. DOI: 10.1016/S0048-9697(99)00071-6.

[19] Grodzińska K, Szarek-Łukawska G. Response of mosses to the heavy metal deposition in Poland an overview. Environ Pollut. 2001;114(3/4):443-451.DOI: 10.1016/S0269-7491(00)00227-X.

[20] Makomaska M. Heavy metals contamination of pinewoods in the Niepołomice Forest (Southern Poland). Bull Acad Polon Sci Biol Cl. 1978;II,26:679-685, WOS:A1978GP04100005.

[21] Grodzińska K, Kazimierczakowa R. Heavy metal content in the plants of Cracow parks. Bull Acad Pol Sci Cl. 1977;V,25(4):227-234.

[22] Godzik B, Kiszka J. Concentration of heavy metals in thalluses of Hypogymnia physodes (L.) Nyl. in the Carna Wisełka and Biała Wisełka catchments. In: Wróbel S, editor. Environmantal degradation of the Czarna Wisełka and Biała Wisełka catchments, Western Carpathians. Studia Nature. 1998;44:73-80.

[23] Godzik B, Szarek-Łukaszewska G. Plant bioindicators in the environmental monitoring. Ecol Chem Eng A. 2005;12(7):677-693.

[24] Fabiszewski J, Brej T, Bielecki K. Plant reactions as indicators of air pollution in the vicinity of a copper smelter. Acta Soc Bot Pol. 1987;56(2):353-363.WOS:A1987K004000014.

[25] Cieśliński S, Jaworska E. Changes in the lichen flora of pine (Pinus silvestris L) under the influence of greenhouse plants cement and lime industry and mining. Act Mycol. 1986;2(1):3-14.

[26] Bystrek J. Epiphytic flora and its disappearance under the influence of air pollution. Zones of environmental pollution in the province Chelm on the basis of licheno- and bioindicative. MC-S University. 1988;43:185-213.

[27] Seaward MRD, Heslop JA, Green D, Bylińska EA. Recent levels of radionuclides in lichens from southwest Poland with particular reference to 134 Cs and 137 Cs. J Environ Radioactiv. 1988;7:123-129.

[28] Kiszka J, Piórecki J. Lichenoindication research in Przemyśl region. J Przemyśl. 1990;19:281-290.

[29] Czarnota P. The content of micro-and macroelements in Hypogymnia physodes thalli in Gorce National Park - Lichenoindication test. National Parks and Nature Reserve. 1995;14(3):69-88.

[30] Sawicka-Kapusta K, Zakrzewska M, Gdula-Argasińska J. Air pollution in the base stations of the Environmental Integrated Monitoring System in Poland. Air Pollut. 2005;XIII:465-475. WOS: 000230300700049 . 
[31] Jóźwiak MA, Jóźwiak M. Influence of cement industry on accumulation of heavy metals in bioindicators. Ecol Chem Eng S. 2009;16(3):323-334.WOS:000272740900006.

[32] Jóźwiak MA, Jóźwiak M, Kozłowski R. Bioindicative assessment methods of urban transport impact on the natural environment. Monographs of Systems Operations Team PAS. 2010;II:177-199.

[33] Jóźwiak MA. The use of indicative organisms in bioindication of land and water environments with the chosen examples. Kielce: Kielce Scientific Society; 2014.

[34] Serafiński W, Szulakowska G, Wielgus-Serafińska E, Sajdak G. Studies on biology of fresh-water snails from Silesian Industrial Area. III. Accumulation and localization of lead in shells and tissues of Planorbariuscorneus (L.). Acta Biol. 1978;5:19-23.

[35] Pieczyńska E. The role of macrophytes in shaping trophic lakes. Ecol News. 1988;34:375-405.

[36] Strzelec M, Serafiński W. Live cycles freshwater planorbid snails in anthropogenic water bodies. Acta Biol Siles. 1994;24:104-117.

[37] Strzelec M. The effects of elevated water temperature on occurrence of freshwater snails in Rybnik dam reservoirs (Upper Silesia, Poland). Folia Malacologica. 1999;7:93-98.

[38] Gorzel M. Kornijów R. Biological evaluation of the quality of river water. Space - The Problems of Biol Sci. 2004;53(2):183-191.

[39] Szoszkiewicz K, Zbierska J, Jusik S, Zgoła T. The assessment method based on macrophyte rivers run in Poland for the purposes of the Water Framework Directive. Messages Drainage and Grasses Area. 2008;LI(4):163-165.

[40] Ellenberg H. Zeigerwerte der Gefäßpflanzen Mitteleuropas, 2. Aufl. Scripta Geobotan. 1979;9:1-122.

[41] Ellenberg H. Belastung und Belastbarkeit von Ökosystemen, Tagungsbericht der Gesellschahh für Ökologie. Giessen: 1972;2:34-42.

[42] Barker MJ. Biological monitoring principles methods and difficulties. In: Barker MJ, editor. Marine ecology and oil pollution. New York: Wiley and Sons. Inc.; 1976;4:41-53.

[43] Bick H. Bioindikatoren und Umweltschutz. Berlin: Dechemniana - Beichefte; 1982.

[44] Burton MAS. Biological monitoring of environmental contaminants (plants). Rapost 32. GEMS Monitoring and Assessment Research Centre. London: King's College London, University of London; 1986.

[45] Vinogradov BV. Remote sansing bioindication errors. In: Bohac J, editor. Bioindycatores ReVIth Int. Conf. Ceskie Budejovice. 1992;4:53-59.

[46] Majstrik V. Principles of Bioindication and Biomonitoring Theoretical Problems and Practical Applications. In: Bohac J, editor. Bioindicatores Deteriorisationi Regions. Ceskie Budejowice, 1992;2:11-23.

[47] Carreras HA, Pignata ML. Biomonitoring of heavy metals and air quality in Cordoba City, Argentina, using transplanted lichens. Environ Pollut. 2002;117:77-87.

[48] Calvelo S, Liberatore S. Applicability of in situ or transplanted lichens for assessment of atmospheric pollution in Patagonia, Argentina. J Atmospher Chem. 2004;49:199-210. DOI: 10.1007/s10874-004-12258.

[49] Conti ME, Tudino M, Stripeikis J, Cecchetti G. Heavy metal accumulation in the lichen Evernia prunastri transplanted at urban, rural and industrial sites in Central Italy. J Atmospher Chem. 2004;49:83-94. DOI: 10.1007/s10874-004-1216-9.

[50] Kosiba P. Biomonitoring of air reactions of mosses in conditions of pollution with industry emissions. Bot U Wroc. 2004;3:74-77.

[51] Sloof JE. Lichens as quantitative biomonitors for atmospheric trace-element deposition, using transplants. Atmospher Environ. 1995;29:11-20.

[52] Garty J, Kauppi M, Kauppi A. The influence of air pollution on the concentration of airborne elements and on the production of stress-ethylene in the lichen Usnea hirta (L) Weber em Mot transplanted in urban sites in Oulu, N Finland. Arch Environ Contam Toxicol. 1997;32:285-290. DOI: 10.1007/s002449900186.

[53] González CM, Orellana LC, Casanovas SS, Pignata ML. Environmental conditions and chemical response of transplanted lichen to an urban area. J Environ Manage. 1998;53:73-81.

[54] Carreras HA, Pignata ML. Biomonitoring of heavy metals and air quality in Cordoba City, Argentina, using transplanted lichens. Environ Pollut. 2002;117:77-87.

[55] Malkholm MM, Bennett JP. Mercury accumulation in transplanted Hypogymnia physodes lichens downwind of Wisconsin chloralkali plant. Water Air Soil Pollut. 1998;102:427-436.

[56] Jensen M, Chakir S, Feige GB. Osmotic and atmospheric dedratation effects in the lichens Hypogymnia physodes, Lobaria pulmonaria, and Peltigera aphthosa: an in vivo study of the chlorophyll fluorescence induction. Photosynthetica. 1999;37(3):393-404.

[57] Conti ME, Cecchetti G. Biological monitoring: lichens as bioindicators of air pollution assessment a review. Environ Pollut. 2001;114:471-492. 
[58] Białońska D, Dayan FE. Chemistry of the lichen Hypogymnia physodes transplanted to an industrial region. J Chem Ecol. 2005;31(12):2975-2991. DOI: 10.1007/s10886-005-8408-x.

[59] Sawicka-Kapusta K. Zakrzewska M, Bydłoń G. Biological monitoring - the useful method for estimation of fair and environment quality. Air Pollut. 2007;XV:353-362.

[60] Jóźwiak M. Accumulation of heavy metals and morphological changes in thalli of Hypogymnia physodes (L.)Nyl.) lichen. Natural Environ Monit. 2007;8/07:51-56.

[61] Cortés E. Investigation of air pollution in Chile using biomonitors. J Radioanalyt Nuclear Chem. 2003;262(1):269.276.

[62] Godinho RM, Freitas MC, Wolterbeek HT. Assessment of lichen vitality during transplantation experiment to a polluted site. J Atmospher Chem. 2004;49(1-3):355-361.

[63] Poličnik H, Batič F, Cvetka RL. Monitoring of short-term heavy metal deposition by accumulation in epiphytic lichens (Hypogymnia physodes (L.) Nyl.). J Atmospher Chem. 2004;49:223-230.

[64] Garty J, Levin T, Lehr H, Tomer S, Hochman A. Interactive effects of UV-B radiation and chemical contamination on physiological parameters in the lichen Ramalina lacer. $\mathrm{J}$ Atmospher Chem. 2004;49:267-289.

[65] Vestergaard NK, Stephansen U, Rasmussen L, Pilegaard K. Airborne heavy metal pollution in the environment of a Danish steel plant. Water Air Soil Pollut. 1986;27(3-4):363-377. DOI: 10.1007/BF00649418.

[66] Motiejūnaité J. Epiphytic lichen community dynamics in deciduous forests around a phosphorus fertiliser factory in Central Lithuania. Environ Pollut. 2007;146:341-350.

[67] Jeran Z, Byrne AR, Batić F. Transplanted epiphytic lichens as biomonitors of air - contamination by natural radionuclides around the Źirowski VRH Uranium Mine, Slovenia. Lichenologist. 1995;27(5):375-385.

[68] Calatayud A, Temple PJ, Barrend E. Chlorophyll a fluorescence emission, xanthophyll cycle activity, and net photosynthetic rate responses to ozone in some foliose and friutcose lichen species. Photosyntetica. 2000;38:281-286.

[69] Brodo IM. Transplanted experiments with corticolus lichens using a new technique. Ecology. 1961;42:838-841.

[70] Mizera A. Soil. Mechanisms of degradation and restoration method. Publication GreenWorld - Environ Protect and Ecol. 2007;1:73-79.

[71] De Jonie H, Freijer JI. Relation between bioavailability and fuel oil hydrocarbon composition in contaminated soils. Environ Sci Technol. 1997;7:389-402.

[72] Czerniawska-Kusza I, Szoszkiewicz K. Biological or Hydromorphological Assessment of Flowing Water on the Example of the River Small Panew. Opole: Department of Land Protection, University of Opole; 2007.

[73] Nałęcz-Jawecki G. Aquatic toxicity test method bioindicative. Biul Farmac. 2003;2:34-39.

[74] Elder JF, Collins JJ, Freshwater molluscs as indicators of bioavailability and toxicity of metals in surface-water systems. Rev Environ Contam Toxicol. 1991;122:37-79.

[75] Jurkiewicz-Karnkowska E, Krolak E. Heavy metal concentrations in molluscs from the Zegrzynski Reservoir and the rivers supplying it. Pol Arch Hydrobiol. 1996;43(3):335-346.

[76] Piotrowski S. Heavy metal contents in shells of Lymnaea peregra (O.F. Müll.) and Lymnaea stagnalis (L.) from a fish pond in the area of Kłeby near Nowogard. Quaternary Studies in Poland, Special Issue. 1999; 281-288.

[77] Van-Balognah K, Fernandez DS, Salanki J. Heavy metal concentrations of Lymnea stagnalis L. in the environs of lake Balaton (Hungary). Wat Res. 1988;22:1205-1210.

[78] Gomot-de Vaufleury A, Kerhoas I. Bull of Environ Contamin and Toxicol. 2000;64(3):434-442.

[79] Coeurdassier M, Scheifler R, de Vaufleury A, Crini N, Saccomani C, Salomon Du Mont L, et al. Earthworms influence metal transfer from soil to snails. Applied Soil Ecol. 2007;35(2):302-310.

[80] Chitmanat C, Pracobsin N, Chaibu P, Traichaiyapom S. The use of acetylcholinesterase inhibition in river snails (Sinotaia ingallsiana) to determine the pesticide contamination in the Upper Ping River. Int J Agricult and Biol. 2008;10(6):658-660.

[81] Parleman H, Meili M. Mercury in macroinvertebrates from Swedish forest lakes: influence of lake type, habitat, life cycle and food quality. Can J Fish Aquat Sci. 1993;50:521-534.

[82] Scott-Fordsmand JJ, Weeks JM, Hopkin SP. Importance of contamination history for understanding toxicity of copper to earthworm Eisenia fetida (Oligochaeta: Annelida), using neutral-red retention assay. Environ Toxicol Chem. 2000;19:1774-1780.

[83] Berger B, Dallinger R. Terrestrial snails as quantitative indicators of environmental metal pollution. Environ Monit Assess. 1993;25:65-84. DOI: 10.1007/BF00549793. 


\title{
BIOINDYKACJA WYZWANIEM NOWOCZESNEJ OCHRONY ŚRODOWISKA
}

\author{
Katedra Ochrony i Kształtowania Środowiska, Uniwersytet Jana Kochanowskiego w Kielcach
}

\begin{abstract}
Abstrakt: Badania i diagnoza zmian środowiskowych do momentu wprowadzenia metod bioindykacyjnych miały wymiar i charakter czysto aparaturowy. Zwrócenie uwagi na reakcje organizmów wrażliwych na te zmiany i posłużenie się nimi w kontroli jakości środowiska otworzyło możliwości rozwoju nowej specjalności naukowej, która jest notowana w literaturze jako bioindykacja. W bioindykacji znajduje swoje miejsce kilka dyscyplin naukowych, takich jak biologia, szeroko rozumiana geografia czy chemia. Łączy ona zatem w sposób czytelny pomiary aparaturowe (wyniki analiz chemicznych), obszary ekspozycji biowskaźników (usytuowanie i odległość od emitora) i przekłada powyższe parametry na reakcje anatomiczne i morfologiczne biowskaźników. Rozwój metod bioindykacyjnych postępuje w dużym tempie i jak zwykle w takich okolicznościach trudno uniknąć braku uporządkowania i pewnego chaosu. Wydaje się więc konieczne rozpoczęcie dyskusji w tym zakresie i poddanie pod rozwagę, czy nie należałoby dla badania określonych toksyn środowiskowych w wybranym typie środowiska wskazać dla nich listy najlepszych organizmów wskaźnikowych.
\end{abstract}

Słowa kluczowe: zanieczyszczenie środowiska, bioindykatory, badania bioindykacyjne, metody bioindykacyjne 